\title{
Review
}

\section{Conservation and natural resource management: where are all the women?}

\author{
Robyn James, Bridget Gibis, Laura Whitford \\ Craig Leisher, Ruth Konia and Nathalie Butt
}

\begin{abstract}
There is evidence from the development and humanitarian sectors that purposeful engagement of women can increase the impact of development. We conducted a literature review to examine whether this is also evident in conservation and natural resource management. The following themes emerged from our review: existing societal and cultural norms affect and generally limit how women can engage in conservation and natural resource management; women interact differently with the environment than men, so if they are excluded, their knowledge and perspectives on particular resources may not be considered in conservation actions; and there is often a lack of resources or dedicated effort by conservation or natural resource management programmes to understand and address the barriers that prevent women's engagement. Although there was evidence of a positive relationship between the engagement of women and environmental outcomes, some studies showed that positive conservation outcomes do not necessarily benefit women, and when women are not considered, conservation activities can perpetuate existing inequities. We conclude that although the importance of integrating gender into conservation is acknowledged in the literature, there is a need to examine how women can be meaningfully engaged in conservation. This must go beyond treating women as a homogenous group, to consider intersectionality including race, ethnicity, age, religion, poverty and disability. In addition, conservation and natural resource
\end{abstract}

RoByn JAMES* (Corresponding author, (i) orcid.org/0000-0001-7301-5703) School of Social Sciences, University of Queensland St Lucia, Brisbane, Queensland 4067, Australia. E-mail rjames@tnc.org

BRIDGET GIBBS (D) orcid.org/0000-0002-6296-0483) School of Geography Planning and Environmental Management, University of Queensland, Brisbane, Australia

LAURA WHITFORD (10 orcid.org/0000-0003-0866-0866) The Nature Conservancy, Melbourne, Australia

Craig Leisher (iㅣ orcid.org/0000-0002-2371-2241) The Nature Conservancy, Nairobi, Kenya

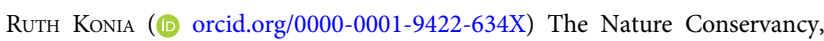
Port Moresby, Papua New Guinea

Nathalie Butt (@) orcid.org/0000-0003-1517-6191) Centre for Biodiversity and Conservation Science, University of Queensland, Brisbane, Australia

${ }^{*}$ Also at: The Nature Conservancy, Asia Pacific Resource Centre, Brisbane, Australia

Received 24 February 2020. Revision requested 29 July 2020.

Accepted 2 December 2020. First published online 5 March 2021. management institutions need to address the inclusion of women in their own staff and programmes.

Keywords Conservation, environment, equity, gender, governance, leadership, natural resource management, women

Supplementary material for this article is available at doi.org/10.1017/So030605320001349

\section{Introduction}

Cender refers to socially constructed characteristics of

$\checkmark$ femininity and masculinity, including cultural norms and roles attributed to women and men. Perceptions of and views on gender vary between societies and can change over time (Zweifel, 1997; Griffin, 2017). Although gender inequality affects everyone, it can be particularly damaging for women and girls (UN WOMEN, 2017). The development sector has long been systematically addressing gender, aiming to engage and empower women in the context of humanitarian and development interventions. There is evidence of benefits when women are intentionally considered in both policy and activities (Duffo, 2012; Taukobong et al., 2016). Many development organizations have developed gender policies that have progressed from simply including women and increasing their participation to a more transformative approach. This involves addressing deeply entrenched patriarchal systems, including cultural and traditional norms that underpin and exacerbate gender-based discrimination, exploitation and violence, and making this work an integral component of programmes and projects (e.g. World Vision, 2017; Save the Children, 2019).

Here, we focus on how conservation can better consider women. Although large conservation organizations are developing and refining gender policies and guidance (e.g. IUCN, 2018; The Nature Conservancy, 2018; Conservation International, 2019; WWF, 2011), the environment sector overall, including both conservation and natural resource management, has been slow to address gender inequity. Conservation is defined here as the protection of wild flora and fauna and their natural habitats, and natural resource management refers to the sustainable utilization of major natural resources such as land, water, forests and fisheries (Muralikrishna \& Manickam, 2017). There is some 
evidence in the peer-reviewed literature that engaging women in natural resource management and conservation efforts leads to improved outcomes. Leisher et al. (2016), for example, cited three studies that identified conservation benefits when women were included. Similarly, a study of natural resource management groups across 20 countries in Latin America, Africa and Asia found that collaboration, solidarity and conflict resolution increased where women were present (Westermann et al., 2005). Other studies have found that greater representation of women leads to more equitable benefit sharing and improved conservation outcomes in forest conservation programmes (e.g. Upreti, 2001; Westerman, 2014; Vollan \& Henry, 2019). However, this is not always the case, and better conservation outcomes do not always lead to more equitable benefits for women and vice versa. For example, where conservation is undertaken within strongly entrenched patriarchal systems, women who are already excluded from decisions around their land and resources are then also precluded from conservation activities and benefits (Doubleday \& Adams, 2019). In addition, women are not a homogenous group and issues of intersectionality are important: age, social class, ethnicity and race are among the factors that determine how and which women are involved in conservation. For example, improved enforcement of forest conservation regulations may deliver conservation or forestry benefits, but can disadvantage the poorest, most marginalized people (including women and men) who rely most on these resources (Agarwal, 2010a).

There are few studies directly measuring the conservation or social benefits of deliberately considering women in conservation. A systematic review of published and unpublished literature found only 17 studies linking gender and conservation (Leisher et al., 2016). Although the publications in our search often included recommendations for how to address gender inequity and better consider women in conservation and natural resource management projects, there was limited evidence in the literature for how this was applied and achieved. We therefore aimed to: (1) examine the existing research on the link between considering women and conservation/natural resource management outcomes, (2) identify the barriers and opportunities that women face in engaging in conservation and natural resource management, and (3) use this analysis to determine research and information gaps and propose a set of recommendations to enable meaningful inclusion of women in conservation and natural resource management.

\section{Methods}

We comprehensively reviewed publications dated 1 January 2000-31 January 2020. We searched the Web of Science (Clarivate Analytics, Philadelphia, USA) and University of Queensland Library (University of Queensland, Brisbane,
Australia) databases using the following search terms: ('gender' OR 'women' OR 'women's empowerment') AND ('conservation' OR 'biodiversity' OR 'natural research management' OR 'environmental management' OR 'climate change' OR 'conservation benefits' OR 'decision-making' OR 'sustainability' OR 'community conservation' OR 'development' OR 'policy' OR 'governance' OR 'protected areas' OR 'leadership').

We included in our analysis articles that had been published in a peer-reviewed journal and addressed gender in at least one of three ways: (1) examining if/how the inclusion of women can improve conservation or natural resource management, (2) describing a project in which women are involved in conservation or natural resource management, or (3) providing recommendations for involving women in conservation or natural resource management. We limited our research to articles published in English and focused on women rather than all genders.

We categorized the articles resulting from our search according to the geographical location of the study site. Two authors separately read each article and identified core themes relating to questions around barriers, opportunities and outcomes of women's engagement in conservation and related fields (Letherby, 2011; Patton, 2015). The two authors then cross-checked the results to ensure consistency. Where there was disagreement on a theme or category for an article, the two authors discussed this and came to a joint conclusion, which was then verified by the other co-authors.

\section{Results}

Our search identified 230 articles with information relating to women and conservation or natural resource management (see full list in the references to Supplementary Table 1). The lead author was female in $70 \%$ of these articles $(n=160)$ and male in only $27 \%$ (in $3 \%$ of articles the gender of the lead author was not determined). Only $17 \%(n=40)$ of the studies focused solely on biodiversity conservation, and over $50 \%$ $(n=118)$ on natural resource management (Fig. 1). Most studies had been conducted in Asia $(31 \%, n=72)$ and Africa $(26 \%$, $\mathrm{n}=60)$, and only $6 \%(\mathrm{n}=24)$ in Australia/Oceania (Fig. 2).

Five themes relating to women in conservation emerged during the analysis of the 230 articles (Fig. 3 , Supplementary Table 1): (1) broader patriarchal, societal and cultural norms affect and generally limit how women can engage in conservation and natural resource management $(53 \%, n=123$ articles), (2) women interact with, use, understand and value the environment differently than men $(52 \%, \mathrm{n}=120),(3) \mathrm{lim}$ ited resources and capability limit women's opportunities to be involved in conservation and natural resource management $(23 \%, n=52)$, (4) women need to substantively and meaningfully included in decision-making to have an impact, which requires dedicated research, effort and resources $(7 \%, n=17)$, and (5) patriarchal systems and the inclusion of women need to be addressed more comprehensively 


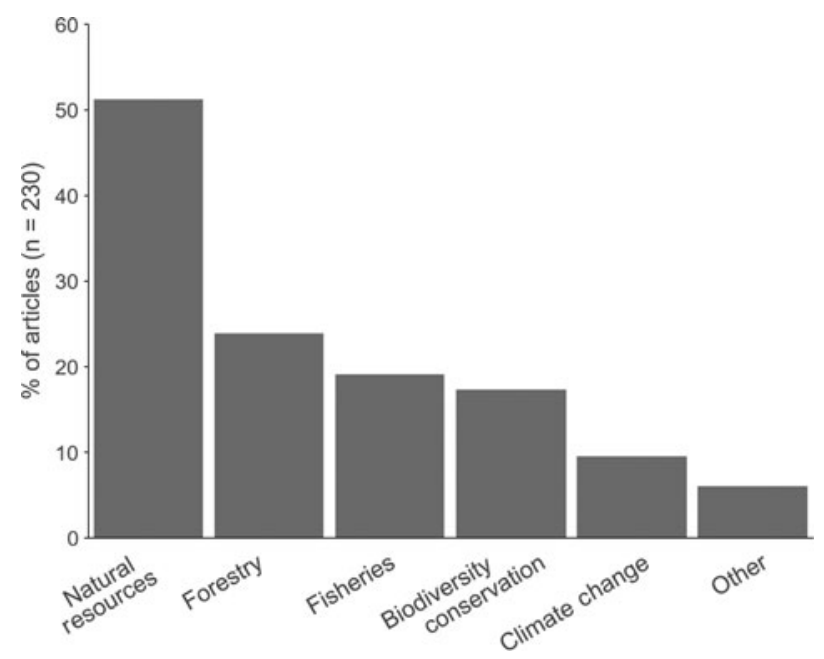

FIG. 1 The articles included in our review were classified by sectors relating to environment and conservation. 'Natural resources' refers broadly to management of land and agricultural systems, water and water catchments, and oceans and reefs. 'Other' refers to some articles that covered women in society, science and/or leadership more generally. Sixty-two articles referred to multiple sectors.

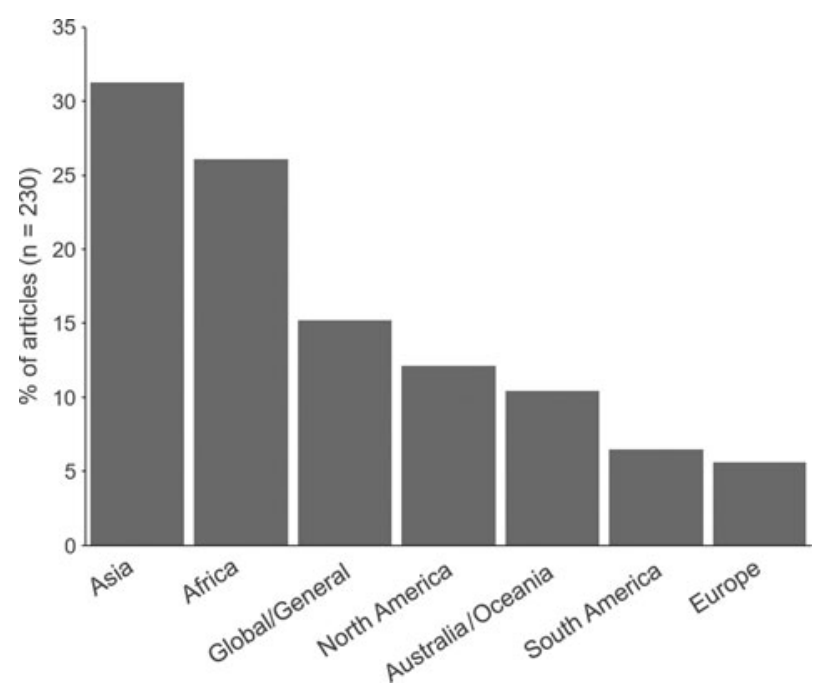

FIG. 2 The articles included in our review were classified by geographical region. 'Global/General' refers to articles that referred to global/multi-regional studies or articles not tied to a specific geographical location.

within conservation and natural resource management institutions, to understand and address barriers to women's engagement ( $7 \%, n=17$; Fig. 3). Ten studies (4\%) explicitly measured and demonstrated positive impacts for conservation when women were involved.

\section{Discussion}

Despite the importance of the issue, only 10 of the 230 studies clearly measured and demonstrated that engaging

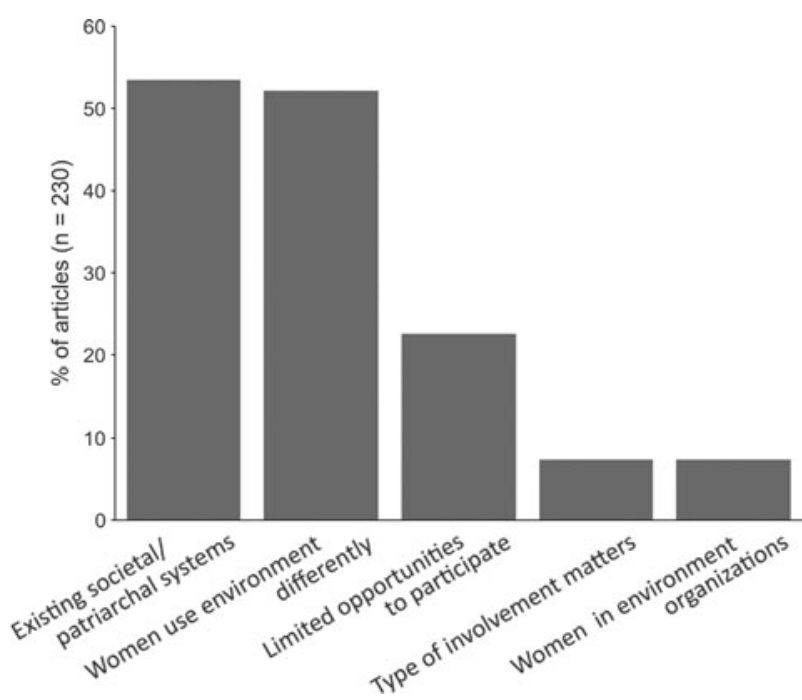

FIG. 3 In the analysis of the 230 articles in this review, five broad themes emerged that affect how and why women engage in conservation and management of natural resources.

women in environment and conservation efforts leads to improved outcomes. For example, a study in Bangladeshi wetlands showed that community compliance with resource management regulations was greater when both men and women played an active role in conserving and managing common pool natural resources (rather than just men; Sultana \& Thompson, 2008). However, several themes emerged relating to barriers and enabling conditions for women to participate in conservation and natural resource management (Fig. 3, Supplementary Table 1). There were five major themes, all of which are interconnected, and many studies we reviewed covered multiple themes.

\section{(1) Existing societal norms affect women in conservation}

More than half of the studies across different countries, ecosystem types and cultural settings reported that women are commonly excluded from decision-making in conservation and natural resource management because of societal or cultural norms. Gender-based (and mostly patriarchal) societal norms shape livelihoods and determine access to and decision-making regarding resources, distribution of benefits and potential social censure for women seeking to access benefits (Buffum et al., 2010; Barclay et al., 2018; Essougong et al., 2019). This reflects the broader exclusion of women in most societies where men hold primary power and predominate in roles of political leadership, perceived moral authority, social privilege and control of property (e.g. Nuggehalli \& Prokopy, 2009; Kleiber et al., 2018; Oliver et al., 2020).

For example, challenges faced by Tanzanian women in the fisheries sector include societal norms that expect women to carry out most household duties and childcare, leaving limited time for fishing. In addition, there are social taboos allowing men to limit women's access to fisheries 
(e.g. when women are menstruating; Bradford \& Katikiro, 2019). Similarly, forestry research shows that women's roles in forestry management are still restricted by a 'masculine gender order' (Richardson et al., 2011, p. 525) that tends to marginalize women's contributions and participation, especially in leadership and decision-making (Varghese \& Reed, 2012; Evans et al., 2017; Essougong et al., 2019). In addition, projects linking conservation to improving livelihoods have in some cases led to further inequities for women, such as increased workload with limited monetary gain (Kariuki \& Birner, 2016).

However, although policies from conservation organizations recommend full participation by women, equitable benefit sharing, and promoting women's empowerment in livelihood and conservation projects, there is less evidence in our review of a deeper understanding of the patriarchal systems within which these projects generally operate, and the limitations these place on women's involvement. A gender analysis of grassland management in Mongolia showed that although there is awareness of the need to increase gender equity, women are rarely fully included in decisions and leadership around community land management in herding communities, and this is then reflected in conservation and natural resource management projects (Ykhanbai et al., 2006). Therefore, simply having women present in decision-making fora without considering the societal context will not resolve this disparity (Staples \& Natcher, 2015; Baynes et al., 2019).

The failure to adequately address prevailing social norms echoes a broader tendency within the conservation community to pursue biological or nature-based and technical solutions without considering societal inequalities that exist where conservation is focused (Calhoun et al., 2016., Westholm \& Arora-Jonsson, 2018). This could be because conservation researchers and practitioners often lack awareness of societal norms or the skills to address them. Conservation organizations typically invest more heavily in natural science/ecology than social science. Social structures may also be perceived as fixed, or outside the scope of conservation work. Regardless of the cause, social inequalities can inadvertently be compounded by conservation efforts and the result is often that women have less decisionmaking power, receive fewer benefits from conservation and carry a greater burden of the environmental labour than men (Westholm \& Arora-Jonsson, 2015).

(2) Women interact with, use, understand and value the environment differently than men

Over $50 \%$ of articles highlighted that women often interact with, use, understand and value the environment differently than men (e.g. Aswani et al., 2015; Purcell et al., 2016; Allendorf \& Yang, 2017; Yang et al., 2018). In marine areas, for example, women commonly undertake inshore fishing, whereas men often undertake coastal and offshore fishing. Therefore, if women are not represented in fisheries decisions and deliberate efforts are not made to acknowledge and incorporate their knowledge, the resources they value are not considered in management planning.

Projects (particularly those linked to the development of livelihoods) may exacerbate inequalities between men and women when their differing use of natural resources is not fully understood or considered. For example, lack of understanding of gender dynamics in the forestry sector in Senegal, and poor representation of women in decisionmaking around land and forest policy, limits women's access to and control over natural resources, with direct, negative implications for their sources of income and livelihoods (Bandiaky-Badji, 2011).

\section{(3) Women lack resources and/or capability to engage in conservation}

There is evidence that limited access to land and resources, for example as a result of insecure land tenure, disproportionately affects women (e.g. Schneider, 2013; St. Clair, 2016; Dyer, 2018). A study of 240 rural women in Nigeria found that women's limited access to and ownership of land limits their ability to harvest forest resources and provide for their families' needs (Adedayo et al., 2010). Similarly, in Senegal the lack of women's representation on local governance councils has affected women's access to resources, including forestry products, water, education and health services (Bandiaky-Badji, 2011). This also reinforces other societal inequities related to gender, including for example the perception that women are dependent on men (Mukadasi \& Nabalegwa, 2007). Women's lack of access is further exacerbated when natural resources such as water become scarcer as a result of climate change (Djoudi \& Brockhaus, 2011). In many countries there are also gaps in documented knowledge about women's land rights and access to land (Meinzen-Dick et al., 2019).

Gender analyses in countries such as Solomon Islands and Brazil show that although women feel their resources need to be better managed, they may lack access to the information and resources needed to contribute meaningfully to decisions (Di Ciommo \& Schiavetti, 2012; Kruijssen et al., 2015). In many parts of the world, women and girls have reduced access to education (particularly secondary and tertiary), which can limit their invitation and perceived legitimacy to be part of conservation actions, and their access to positions within conservation and natural resource management organizations. An analysis across Bolivia, Mexico, Uganda and Kenya found the likelihood that a woman would be entrusted with the responsibility of representing the household on a forestry committee increased with her level of education (Coleman \& Mwangi, 2013), demonstrating that lack of access to education can be a barrier for women, preventing them from contributing to conservation and natural resource management. 


\section{(4) Women need to be substantively and meaningfully included in conservation}

Gender-disaggregated data showing the number of women and men involved in conservation and natural resource management are necessary to demonstrate impacts of including women, but looking beyond the numbers we also need to understand how women are involved and what power and agency they have over conservation and resource management (Call \& Sellers, 2019; Cook et al., 2019). For example, an examination of forestry conservation programmes in India showed that greater representation of women led to more equitable benefit sharing and improved conservation outcomes, with forest cover in the study areas increasing by $11 \%$. However, for these benefits to be realized, women needed to make up at least $25-30 \%$ of the decisionmaking group (Agarwal, 2010b). Several authors noted that decision-making bodies need to include at least 30\% women for them to effectively influence decisions (Agarwal, 2010a; Butler, 2013).

It is also important to consider the adequacy of the tools being used measure and understand women's role in conservation. For example, household surveys in which only one representative is interviewed can mask substantial differences between genders within the household (Verma, 2014). In addition, gender-neutral terms such as 'fishers', intended to be inclusive, can mask the different realities of women and men engaged in the fishing sector, or conceal that data are primarily being captured on men's experience (Kleiber et al., 2014). Therefore, failure to conduct an adequate gender analysis can make it difficult to ensure equitable representation, which then disproportionately disadvantages women (Molden et al., 2014). Forestry research in India and Nepal found that although women spend more time than men using and managing forest resources, they face systemic exclusion and denial of benefit from these resources (Aditya, 2016). It is also important that these analyses seek to reflect the complexity of gender, to capture the perspectives of individuals who do not identify within a binary gender concept, reflect intersectionality (Kojola, 2019) and avoid treating women or men as homogenous groups (Westervelt, 2018). The importance of considering intersectionality is illustrated in a study from Sulawesi, Indonesia, where women's active participation in decisionmaking appeared to be more limited in mixed-ethnicity communities, compared to more ethnically homogeneous areas (Colfer et al., 2015).

\section{(5) Inclusion of women needs to be addressed within conservation institutions}

There are limited published data outlining how conservation organizations consider gender within their own institutions (Jones \& Solomon, 2019), and a tendency to view gender as an issue only for low-income and emerging economies, and community development (Westberg \& Powell, 2015). However, there is evidence of women being excluded within organizations focused on conservation and natural resource management, in external-facing projects and programmes, and in research and policy-setting contexts (Jones \& Solomon, 2019). For example, the number of women occupying leadership positions on many conservation boards in Norway remains small (Lundberg, 2018), despite research showing the improved environmental performance and financial sustainability of organizations with gender-diverse boards (Glass et al., 2015; Hansen et al., 2016).

Traditional gender roles are commonly reflected within conservation organizations (Mahour, 2016). For example, women often occupy interpretive, communicative and administrative roles (with a focus on so-called soft skills), and men are over-represented in positions that are more leadership-oriented and risk-taking or involve fieldwork (Westberg \& Powell, 2015; Jones \& Solomon, 2019). This often leaves women performing lower status tasks, rather than playing the roles of scientific experts and decision-makers that are more highly valued and more visible in these organizations (CohenMiller et al., 2020; Westberg \& Powell, 2015). Women also carry out more office housekeeping tasks that are unrelated to their core responsibilities, such as taking notes and organizing and coordinating events (Westberg \& Powell, 2015). This in turn influences how conservation and natural resource management work and research are undertaken, for example which research questions are asked, which work is prioritized and who is considered. We found that $70 \%$ of articles relating to gender and conservation had female lead authors, which suggests that these research questions are less likely to be investigated if women are not in research positions.

\section{Conclusion}

Research shows that men benefit from and participate in conservation more than women but often there is limited commitment to addressing this (Schneider, 2013; Farnworth et al., 2015; Razafindratsima \& Dunham, 2015). Our review identified significant and persistent barriers to women's full and meaningful participation in conservation and natural resource management efforts. Challenges include heavier workloads around caring and providing for the household (this was evident in every cultural context studied), lack of understanding of the gendered use of resources, and the different access to resources between men and women. There is a persistent perception that men should be the decision makers and leaders in most contexts, both within conservation/ natural resource management organizations and in communities where this work is undertaken. There is also limited 
research on understanding women's aspirations and agency within conservation and natural resource management. Overall, the conservation sector is not yet considering gender equality as an imperative (Schmitt, 2014).

We recommend the following actions to address these challenges: (1) Comprehensive gender and systems analysis should be undertaken prior to and during project and programme implementation, to ensure a nuanced, locally relevant understanding of gender roles and norms, and how these might intersect with conservation and natural resource management efforts (Molden et al., 2014). (2) Internal gender audits should be conducted within conservation and natural resource management organizations, which could include setting targets for women's representation in high-status science and leadership positions, noting that women's participation appears to be necessary, but not sufficient, for improved decision-making (Butler, 2013). Recommendations from these audits should then be implemented, measured and results reported back to staff and partners. (3) There is also a need to better understand what women's leadership and empowerment means in the context of conservation. This could be addressed at least partially by applying theoretical frameworks from the social sciences that aim to more deeply understand and address gender inequity, power and patriarchy, and the complex interplay of social and cultural norms (Eagly, 2007; Gaard, 2015; van Oosten et al., 2017; Weldon, 2019). (4) Women need to be actively encouraged to lead research and publish their findings. Evidence suggests that gender-diverse research groups produce higher-quality science and are cited more than single-gender groups, yet women researchers may struggle to access the same resources as their men counterparts to conduct and promote their research (Campbell et al., 2013). (5) The conservation sector needs to acknowledge that women are not a homogenous group and that wealth, disability, education, ethnicity, race and other aspects interact to affect women's opportunities to engage in conservation. This requires the conservation sector to draw from the social sciences and humanitarian and development sector. (6) Efforts are required to value women's knowledge, and to enable them to share their knowledge and experience regardless of their formal education. Women often have intimate knowledge of their resources, but lack of formal education limits their access to projects. Specific efforts and resources need to be directed towards engaging women who are excluded from conservation projects because of limited literacy, financial literacy, experience and confidence in the use of tools and technologies. (7) The conservation sector also needs to work directly with men to improve their understanding of the negative impacts of gender inequality and to be accountable in actively addressing these challenges. This is important to mitigate potential risks to women when social and power dynamics are challenged.
This review highlighted significant gaps in how the conservation and natural resource management sector addresses inequity for women. It is vital that the conservation sector prioritizes gender equity both within the organizations that guide and implement conservation work as well as in the places where conservation projects are implemented. This will require affirmative action so that women can both benefit from and influence conservation to the same extent as men.

Acknowledgements This research received no specific grant from any funding agency or commercial or not-for-profit sectors. We thank K. Lyons, H. Possingham and S. Mangubhai and J. Fisher for their guidance, two anonymous reviewers for their critiques, and the Oryx editorial team for their help in finalizing the article.

Author contributions Study design: led by RJ with LW, BG; data analysis and writing: led by RJ with BG, LW, CL, RK, NB.

\section{Conflicts of interest None.}

Ethical standards Our analysis is based on data collected from other peer-reviewed, published studies. No ethical approval was required for this research, and it otherwise abides by the Oryx guidelines on ethical standards.

\section{References}

Adedayo, A.G., Oyun, M.B. \& Kadeba, O. (2010) Access of rural women to forest resources and its impact on rural household welfare in north central Nigeria. Forest Policy and Economics, 12, 439-450.

Adity A, S.K. (2016) Role of women in environmental conservation. International Journal of Political Science and Development, 4, 140-145. Agarwal, B. (2010a) Does women's proportional strength affect their participation? Governing local forests in South Asia. World Development, 38, 98-112.

Agarwal, B. (2010b) The impact of women in Nepal's community forestry management. ICIMOD, Sustainable Mountain Development, 57, 26-29.

Allendorf, T.D. \& Allendorf, K. (2013) Gender and attitudes toward protected areas in Myanmar. Society \& Natural Resources, 26, 962-976.

Allendorf, T. \& YANG, J. (2017) The role of gender in local residents' relationships with Gaoligongshan Nature Reserve, Yunnan, China. A Multidisciplinary Approach to the Theory and Practice of

Sustainable Development, 19, 185-198.

Alvarez, I. \& Lovera, S. (2016) New times for women and gender issues in biodiversity conservation and climate justice. Development, $59,263-265$.

Aswani, S., Flores, C. \& Broitman, B. (2015) Human harvesting impacts on managed areas: ecological effects of socially-compatible shellfish reserves. Reviews in Fish Biology and Fisheries, 25, 217-230.

BANDIAKY-BADJI, S. (2011) Gender equity in Senegal's forest governance history: why policy and representation matter. International Forestry Review, 13, 177-194.

Barclay, K., McClean, N., Foale, S., Sulu, R. \& Lawless, S. (2018) Lagoon livelihoods: gender and shell money in Langalanga, Solomon Islands. Maritime Studies, 17, 199-211.

Baynes, J., Herbohn, J., Gregorio, N., Unsworth, W. \& Tremblay, E.H. (2019) Equity for women and marginalized groups in patriarchal societies during forest landscape restoration: the 
controlling influence of tradition and culture. Environmental Conservation, 46, 241-246.

Boyer-Rechlin, B. (2010) Women in forestry: a study of Kenya's Green Belt Movement and Nepal's Community Forestry Program. Scandinavian Journal of Forest Research, 25, 69-72.

Bradford, K. \& Katikiro, R.E. (2019) Fighting the tides: a review of gender and fisheries in Tanzania. Fisheries Research, 216, 79-88.

Buffum, B., Lawrence, A. \& Temphel, K.J. (2010) Equity in community forests in Bhutan. The International Forestry Review, 12, 187-199.

Butler, S. (2013) A Critical Mass of Women on the Board of Directors as Critical Influencers. Preprint available at SSRN, 1 August 2013. ssrn.com/abstract $=2304828$ [accessed 9 December 2020].

Byrne, M., Broadhurst, L., Leishman, M. \& Belov, K. (2018) Women in conservation science making a difference. Pacific Conservation Biology, 24, 209.

Calhoun, S., Conway, F. \& Russell, S. (2016) Acknowledging the voice of women: implications for fisheries management and policy. Marine Policy, 74, 292-299.

Call, M. \& Sellers, S. (2019) How does gendered vulnerability shape the adoption and impact of sustainable livelihood interventions in an era of global climate change? Environmental Research Letters, 14, 15.

Campbell, L.G., Mehtani, S., Dozier, M.E. \& Rinehart, J. (2013) Gender-heterogeneous working groups produce higher quality science. PLOS ONE, 8, e79147-e79147.

Chhetri, B.B.K., Johnsen, F.H., Konoshima, M. \& Yoshimoto, A. (2013) Community forestry in the hills of Nepal: determinants of user participation in forest management. Forest Policy and Economics, 30, 6-13.

Christoff, P. \& Sommer, J. (2018) Women's empowerment and climate change adaptation in Gujarat, India: a case-study analysis of the local impact of transnational advocacy networks. Sustainability, 10, 1920.

Coleman, E.A. \& Mwangi, E. (2013) Women's participation in forest management: a cross-country analysis. Global Environmental Change, 23, 193-205.

Colfer, C.J.P., Achdiawan, R., Roshetko, J.M., Mulyoutami, E., Yuliani, E.L., Mulyana, A. et al. (2015) The balance of power in household decision-making: encouraging news on gender in southern Sulawesi. World Development, 76, 147-164.

CohenMiller, A.S., Koo, S., Collins, N. \& Lewis, J.L. (2020) EXPOsing gender in science: a visual analysis with lessons for gender awareness and science diplomacy. Gender Technology \& Development, 24, 215-235.

Conservation International (2019) Guidelines for Intergrating Gender and Social Equity into Conservation Programming. conservation.org/docs/default-source/publication-pdfs/integratinggender-and-social-equity-into-conservation-programming-2019.pdf [accessed 9 February 2020].

Cook, N., Grillos, T. \& Andersson, K. (2019) Gender quotas increase the equality and effectiveness of climate policy interventions. Nature Climate Change, 9, 330-334.

Di Ciommo, R.C. \& SchiavetTi, A. (2012) Women participation in the management of a marine protected area in Brazil. Ocean \& Coastal Management, 62, 15-23.

Djoudi, H. \& Brockhaus, M. (2011) Is adaptation to climate change gender neutral? Lessons from communities dependent on livestock and forests in northern Mali. The International Forestry Review, $13,123-135$.

Doubleday, K.F. \& Adams, P.C. (2019) Women's risk and well-being at the intersection of dowry, patriarchy, and conservation: the gendering of human-wildlife conflict. Environment and Planning E: Nature and Space, 3, 976-998.
Duflo, E. (2012) Women empowerment and economic development. Journal of Economic Literature, 50, 1051-1079.

DYeR, M. (2018) Ungrounded cosmopolitanism: intersections of moral responsibility and gender in environmental activism in rural Solomon Islands. Women's Studies International Forum, 67, 128-135.

EAGLY, A.H. (2007) Female leadership advantage and disadvantage: resolving the contradictions. Psychology of Women Quarterly, 31, 1-12.

Essougong, U.P.K., Foundjem-Tita, D. \& Minang, P.A. (2019) Addressing equity in community forestry: lessons from 20 years of implementation in Cameroon. Ecology and Society, 24, 9.

Evans, K., Flores, S., Larson, A.M., Marchena, R., Múller, P. \& Pikitle, A. (2017) Challenges for women's participation in communal forests: experience from Nicaragua's Indigenous territories. Women's Studies International Forum, 65, 37-46.

Farnworth, C.R., Baudron, F., Andersson, J.A., Misiko, M., Badstue, L. \& Stirling, C.M. (2015) Gender and conservation agriculture in East and Southern Africa: towards a research agenda. International Journal of Agricultural Sustainability, 14, 1-24.

GAARD, G. (2015) Ecofeminism and climate change. Women's Studies International Forum, 49, 20-33.

Glass, C., Cook, A. \& Ingersoll, A.R. (2015) Do women leaders promote sustainability? Analyzing the effect of corporate governance composition on environmental performance. Business Strategy and the Environment, 25, 495-511.

Griffin, G. (2017) A Dictionary of Gender Studies. Oxford University Press, Oxford, UK.

Hansen, E., Conroy, K., Toppinen, A., Bull, L., Kutnar, A. \& PANWAR, R. (2016) Does gender diversity in forest sector companies matter? Canadian Journal of Forest Research, 46, 1255-1263.

IUCN (2018) Gender Equality and Women's Empowerment Policy: Mainstreaming Gender-Responsiveness within the IUCN Programme of Work. IUCN, Gland, Switzerland.

Jones, M.S. \& Solomon, J. (2019) Challenges and supports for women conservation leaders. Conservation Science and Practice, 1, e36.

Kariuki, J. \& Birner, R. (2016) Are market-based conservation schemes gender-blind? A qualitative study of three cases from Kenya. Society \& Natural Resources, 29, 432-447.

Kleiber, D., Harris, L.M. \& Vincent, A.C. (2014) Gender and small-scale fisheries: a case for counting women and beyond. Fish and Fisheries, 16, 547-562.

Kleiber, D., Harris, L. \& Vincent, A.C.J. (2018) Gender and marine protected areas: a case study of Danajon Bank, Philippines. Maritime Studies, 17, 163-175.

Kojola, E. (2019) Indigeneity, gender and class in decision-making about risks from resource extraction. Environmental Sociology, $5,130-148$.

Kruijssen, F., Albert, J., Morgan, M., Boso, D., Siota, F., Sibiti, S., Schwarz, A.-M. (2015) Livelihoods, Markets, and Gender Roles in Solomon Islands: Case Studies from Western and Isabel Provinces. Project Report: AAS-2013-22. CGIAR Research Program on Aquatic Agricultural Systems, Penang, Malaysia.

Leisher, C., Temsah, G., Booker, F., Day, M., Samberg, L., Prosnitz, D. et al. (2016) Does the gender composition of forest and fishery management groups affect resource governance and conservation outcomes? A systematic map. Environmental Evidence, 5, 1-10.

Letherby, G. (2011) Feminist methodology. In The SAGE Handbook of Innovation in Social Research Methods (eds M. Williams \& W.P. Vogt), pp. 62-79. Sage Publications Ltd, London, UK.

LUNDBERG, A.K.A. (2018) Gender equality in conservation management: reproducing or transforming gender differences through local participation? Society \& Natural Resources, 31, 1266-1282.

MAhour, K. (2016) Role of women in environment conservation. Journal of Advanced Laboratory Research in Biology, 7, 17-26. 
McNutt, K. \& Béland, D. (2015) Implementing an integrated governance strategy: the quest for gender mainstreaming in Canada. American Review of Canadian Studies, 45, 467-485.

Meinzen-Dick, R., Quisumbing, A., Doss, C. \& Theis, S. (2019) Women's land rights as a pathway to poverty reduction: framework and review of available evidence. Agricultural Systems, 172, 72-82.

Molden, D., Verma, R. \& Sharma, E. (2014) Gender equality as a key strategy for achieving equitable and sustainable development in mountains: the case of The Hindu Kush-Himalayas. Mountain Research and Development, 34, 297-300.

Mukadasi, B. \& Nabalegwa, M. (2007) Gender mainstreaming and community participation in plant resource conservation in Buzaya county, Kamuli district, Uganda. African Journal of Ecology, 45, 7-12.

Muralikrishna, I.V. \& Manickam, V. (2017) Natural resource management and biodiversity conservation. In Environmental Management (eds I.V. Muralikrishna \& V. Manickam), pp. 23-35. Butterworth-Heinemann, Oxford, UK.

Nuggehalli, R.K. \& Prokopy, L.S. (2009) Motivating factors and facilitating conditions explaining women's participation in co-management of Sri Lankan forests. Forest Policy and Economics, $11,288-293$.

Oliver, D.M., Zheng, Y., Naylor, L.A., Murtagh, M., Waldron, S. \& PENG, T. (2020) How does smallholder farming practice and environmental awareness vary across village communities in the karst terrain of southwest China? Agriculture Ecosystems \& Environment, 288, 9.

Patton, M. (2015) Qualitative Research \& Evaluation Methods: Integrating Theory and Practice. Sage Publications, Inc., Thousand Oaks, USA.

Purcell, S.W., Ngaluafe, P., Aram, K.T. \& Lalavanua, W. (2016) Trends in small-scale artisanal fishing of sea cucumbers in Oceania. Fisheries Research, 183, 99-110.

Razafindratsima, O. \& Dunham, A.E. (2015) Editorial: increasing women's participation in community-based conservation: key to success? Madagascar Conservation \& Development, 10, 45-47.

Richardson, K., Sinclair, A.J., Reed, M.G. \& Parkins, J.R. (2011) Constraints to participation in Canadian forestry advisory committees: a gendered perspective. Canadian Journal of Forest Research, 41, 524-532.

Save the Children (2019) Gender Equality 2019-2021 Strategy. Save the Children International, London, UK.

Sснмітт, M. (2014) Gender awareness in European alpine protected area management: achievements, shortcomings, and the way forward. Mountain Research and Development, 34, 291-296.

SCHNeIder, H. (2013) The future face of conservation: could it be female? Oryx, 47, 1-2.

St. Clair, P.C. (2016) Community forest management, gender and fuelwood collection in rural Nepal. Journal of Forest Economics, $24,52-71$.

Staples, K. \& Natcher, D.C. (2015) Gender, decision making, and natural resource co-management in Yukon. Arctic, 68, 356-366.

Sultana, P. \& Thompson, P. (2008) Gender and local floodplain management institutions: a case study from Bangladesh. Journal of International Development, 20, 53-68.

Taukobong, H.F.G., Kincaid, M.M., Levy, J.K., Bloom, S.S., Platt, J.L., Henry, S.K. \& Darmstadt, G.L. (2016) Does addressing gender inequalities and empowering women and girls improve health and development programme outcomes? Health Policy and Planning, 31, 1492-1514.
The Nature Conservancy (2018) Gender Guidance. The Nature Conservancy, Arlington County, USA.

UN WOMEN (2017) Spotlight on Sustainable Development Goal 5: Achieve Gender Equality and Empower All Women and Girls. unwomen.org/en/digital-library/multimedia/2017/7/infographicspotlight-on-sdg-5 [accessed 19 September 2019].

UPRETI, B.R. (2001) Contributions of community forestry in rural social transformation: some observations from Nepal. Journal of Forest and Livelihood, 1, 31-33.

van Oosten, E.B., Buse, K. \& Bilimoria, D. (2017) The leadership lab for women: advancing and retaining women in STEM through professional development. Frontiers in Psychology, 8, 2138.

VArghese, J. \& ReED, M.G. (2012) Theorizing the implications of gender order for sustainable forest management. International Journal of Forestry Research, 2012, 257280.

Verma, R. (2014) Business as unusual: the potential for gender transformative change in development and mountain contexts. Mountain Research and Development, 34, 188-196.

Vollan, B. \& Henry, A.D. (2019) Diversity in decision-making. Nature Climate Change, 9, 258-259.

WELDON, S.L. (2019) Inclusion and exclusion: contributions of a feminist approach to power. In Gender Innovation in Political Science: New Norms, New Knowledge (eds M. Sawer \& K. Baker), pp. 61-89. Springer International Publishing, Cham, Switzerland.

Westberg, L. \& Powell, S. (2015) Participate for women's sake? A gender analysis of a Swedish collaborative environmental management project. Society \& Natural Resources, 28, 1233-1248.

Westerman, K. (2014) Guidelines for Integrating Gender into Conservation Projects. Conservation International, Crystal City, USA.

Westermann, O., Ashby, J. \& Pretty, J. (2005) Gender and social capital: the importance of gender differences for the maturity and effectiveness of natural resource management groups. World Development, 33, 1783-1799.

Westervelt, M.O. (2018) A co-wife for the cow: gender dimensions of land change and livelihood shift among Loita Maasai of Southern Kenya. Human Ecology, 46, 815-829.

Westholm, L. \& Arora-Jonsson, S. (2015) Defining solutions, finding problems: deforestation, gender, and REDD plus in Burkina Faso. Conservation \& Society, 13, 189-199.

Westholm, L. \& ARORA-JonsSON, S. (2018) What room for politics and change in global climate governance? Addressing gender in co-benefits and safeguards. Environmental Politics, 27, 917-938.

World Vision (2017) Gender Equality: World Vision Australia's Public Policy Position. worldvision.com.au/global-issues/work-wedo/gender [accessed 19 September 2019].

WWF (2011) Policy on Gender. worldwildlife.org/publications/wwfgender-policy [accessed 19 September 2019].

Yang, Y.C.E., Passarelli, S., Lovell, R.J. \& Ringler, C. (2018) Gendered perspectives of ecosystem services: a systematic review. Ecosystem Services, 31, 58-67.

Ykhanbai, H., Odgerel, T., Bulgan, E. \& Naranchimeg, B. (2006) Herder women speak out - towards more equitable co-management of grasslands and other natural resources in Mongolia. In Social and Gender Analysis in Natural Resource Management: Learning Studies and Lessons from Asia (ed. R. Vernooy), pp. 181-205. Sage Publications India Pvt Ltd, New Delhi, India.

Zweifel, H. (1997) The gendered nature of biodiversity conservation. NWSA Journal, 9, 107-123. 